\title{
確率弾塑性モデルを用いた履歴特性に対する 地盤物性の不確実性の影響評価
}

\author{
羽場 一基 ${ }^{1} \cdot$ 堀田 渉 ${ }^{2} \cdot$ 園部 秀明 ${ }^{3} \cdot$ 畑 明仁 ${ }^{4} \cdot$ 渡辺 和明 $5 \cdot$ 堀 宗朗 6 \\ 1 正会員 大成建設株式会社 原子力本部（ $\bar{T} 163-0606$ 東京都新宿区西新宿 1-25-1） \\ E-mail: hb-kzm00@pub.taisei.co.jp \\ 2 正会員 大成建設株式会社 原子力本部（ $\bar{T} 163-0606$ 東京都新宿区西新宿 1-25-1） \\ E-mail: ht-wtr00@pub.taisei.co.jp \\ 3 正会員 大成建設株式会社 原子力本部（ $\bar{T} 163-0606$ 東京都新宿区西新宿 1-25-1） \\ E-mail:snbhda00@pub.taisei.co.jp \\ 4 正会員 大成建設株式会社 技術センター（厂 245-0051 神奈川県横浜市戸塚区名瀬町 344-1） \\ E-mail: hata@ce.taisei.co.jp \\ 5 正会員 大成建設株式会社 原子力本部（ 163-0606 東京都新宿区西新宿 1-25-1） \\ E-mail: kwatanab@ce.taisei.co.jp \\ ${ }^{6}$ 正会員 東京大学 地震研究所（ $\overline{1} 113-0032$ 東京都文京区弥生 1-1-1） \\ E-mail: hori@eri.u-tokyo.ac.jp
}

\begin{abstract}
本論文では，スペクトル展開を用いた確率リターンマッピングアルゴリズムによる確率弾塑性モデルを非排 水粘土の応力-歪関係に適用し，地盤物性の不確実性が履歴特性に与える影響を評価した。 その結果，弾塑性モ デルを確率空間へ拡張することで, 単純な弾完全塑性 von Mises モデルを用いた場合でも, 現実に近い履歴特 性を評価できることがわかった。さらに, 地盤物性の不確実性が応答場に与える影響を計算することで, 動的 変形特性の不確実性を評価することができた。
\end{abstract}

Key Words: elasto-plasticity, stochastic modeling, soil uncertainty, return mapping algorithm, hysteresis loop, dynamic deformation characteristics

\section{1. はじめに}

国内外の設計基準に対する性能設計法及び信頼性設 計法の導入や，国内の原子力発電所を対象とした確率 論的リスク評価の義務付け等, 設計条件の不確実性を 確率論的にモデル化し構造物の安全性やリスクを合理 的に評価する取り組みが進んでいる。特に，土木構造 物の確率論的耐震安全性評価においては，地盤物性の 不確実性の取り扱いは重要な課題となっている.

確率論的な評価に用いられる手法としては, 地盤物 性等の不確実パラメータを確率的な乱数として与え, 多 数回の計算を行うことにより解のばらつきを評価する モンテカルロシミュレーション (以下, MCS) が一般 的である. MCS は極めて沉用的で解析手法に因らず適 用できるが計算負荷が高いという課題がある。その代 替手法の候補として, スペクトル確率有限要素法1)（以 下，SSFEM）が挙げられる. SSFEM では，不確実性 を考慮する確率変数にスペクトル展開を適用すること で，一回の計算で応答場のばらつきを評価することが 可能となるため, 計算負荷の軽減が期待できる。しか し, 材料非線形性の確率論的な取り扱いが容易ではな いため, SSFEM を非線形問題へ適用した例は少ない.
非線形 SSFEM の例の一つとして, Anders and Hori による非線形 $\mathrm{SSFEM}^{2), 3)}$ がある。この非線形 SSFEM はヤング率の不確実性に対して bounding medium 理 論 ${ }^{4)}$ を適用したもので, 確率モデルの挙動の上限と下 限を効率的に評価できる. しかし, 材料の降伏は決定論 的な取り扱いがなされており, 確率的な降伏に伴う応答 場のばらつきを定量的に評価することは難しい，その ため, 物性場のばらつきを考慮した確率的な降伏を評 価するための確率弾塑性モデルの開発が行われている.

Jeremic らは応力の確率分布を応力確率空間上の移流 拡散方程式で与える Fokker-Planck-Kolmogorov 方程式 （以下，FPK 方程式）を用いて評価する確率弾塑性モデ ル5) 10) を提案し, 非線形 SSFEM に適用した ${ }^{11)}$.こ のモデルでは詳細な確率分布を計算可能であるが, 全 積分点上で FPK 方程式を評価する必要があるため, 計 算コストが非常に大きいという課題がある.さらに, 確 率分布を確率空間上の移流拡散として評価することか ら, ヤング率や材料強度等の地盤物性の不確実性が応 答場に与える影響を独立に評価することは困難である.

そのような課題を解決するため, 筆者らは材料の降 伏を確率的に取り扱い, 応力の期待值と分散を評価す るためのスペクトル確率リターンマッピングアルゴリ 
ズム（以下，SSRMA）を提案した12),13). SSRMA は 降伏における応力更新手法であるリターンマッピング アルゴリズムに対して，1次のスペクトル展開を適用し た確率弾塑性モデルである. SSRMA では, 降伏に伴う 応答場の期待值と分散を効率よく評価することができ, ヤング率や材料強度のばらつきが応答場に与える影響 を定量的に評価できる。

近年, 確率弾塑性モデルを地盤の非線形特性の評価 に適用することが提案されている14)。この評価は, 地 盤の非線形特性が地盤を構成する様々な土粒子の平均 挙動で与えられるという解釈に基づく. 地盤は様々な材 料強度を持つ土粒子で構成されており, 歪が与えられ ると, 土粒子の一部は弾性状態で, 一部は降伏し塑性 状態となる. その結果, 土粒子の平均挙動として与え られる地盤の非線形特性には, 小さい歪レベルから大 きい歪レベルまでなめらかな非線形特性が現れる。こ のような解釈に基づけば，確率弾塑性モデルを用いて， 土粒子の物性のばらつきを考慮した確率的な降伏を評 価することで, 簡単な構成則から現実的な地盤の非線形 特性が得られる可能性がある. 実際, Sett らは, FPK 方程式による確率弾塑性モデルを非排水粘土の動的変 形特性の評価に適用し, 土粒子のせん断弾性係数とせ ん断強度のばらつきを考慮することで, 現実に近い剛 性や減衰を評価できることを示した ${ }^{14)}$ 。しかし，単純 な FPK 方程式による確率弾塑性モデルでは, せん断弾 性係数とせん断強度のばらつきが応答場に与える影響 を独立に評価できないため, 動的変形特性の不確実性 を評価できていない，そこで，本論文では，SSRMAを 用いて非排水粘土に対する履歴曲線及び動的変形特性 を数值解析的に評価することで, 確率弾塑性モデルを 用いた地盤の履歴特性評価の有効性と土粒子のせん断 弾性係数及びせん断強度のばらつきが履歴特性に与え る影響を整理する。

本論文の構成は以下の通りである. 2 章で, スペクト ル展開を用いた確率リターンマッピングアルゴリズム の概要を示す. 次に, 3 章で, 履歴特性の評価に用いる せん断弾性係数 $G_{0}$ と非排水せん断強度 $S_{u}$ を既存の標 準貫入試験の結果を用いて整理する. その後, 動的変 形試験を想定した数值実験を実施し, 履歴曲線, 剛性 $G / G_{0}-\gamma$ 関係及び減衰 $h-\gamma$ 関係を評価し, 地盤を構 成する土粒子のせん断弾性係数とせん断強度のばらつ きによる影響を整理する。

\section{2. スペクトル展開を用いた確率リターンマッ ピングアルゴリズムの概要}

ここでは, 降伏における応力更新手法であるリター ンマッピングアルゴリズムを整理した上で, 筆者らに

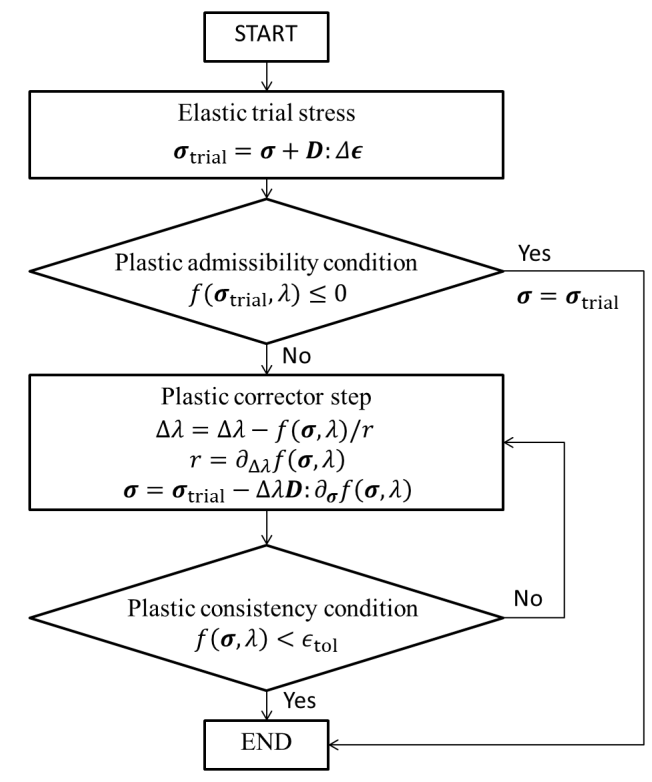

図-1 陰的弾性予測子/リターンマッピングアルゴリズムの評 価フロー

より提案されたスペクトル展開を用いた確率リターン マッピングアルゴリズム ${ }^{12), 13)}$ の概要を示す.

\section{(1) リターンマッピングアルゴリズムの整理}

塑性流れ理論では, 材料が降伏する基準として, 相 当応力 $\sigma_{\mathrm{eq}}$ と降伏応力 $\sigma_{\mathrm{Y}}$ を用いた降伏関数

$$
f(\boldsymbol{\sigma}, \lambda)=\sigma_{\mathrm{eq}}(\boldsymbol{\sigma}, \lambda)-\sigma_{\mathrm{Y}}(\lambda)
$$

を定義し, 以下の制約条件により降伏における応力を 更新する.

$$
d \lambda \geq 0, \quad f \leq 0, \quad d \lambda f=0
$$

ここで, $\sigma$ は応力, $\lambda$ は塑性乗数である.これらの時 間積分を解く手法の一つが, 陰的弾性予測子/リターン マッピングアルゴリズムである15). 図-1に陰的弾性予 測子/リターンマッピングアルゴリズムの評価フローを 示す. 陰的弾性予測子/リターンマッピングアルゴリズ ムでは, 各時間ステップで歪増分 $\Delta \epsilon$ が与えられた時, 弾性であると仮定して弾性予測応力 $\sigma_{\text {trial }}$ を評価する.

$$
\sigma_{\text {trial }}=\sigma+D: \Delta \epsilon
$$

ここで, $D$ は剛性テンソルである. 弾塑性体の場合は, この弾性予測応力が正しい解であるとは限らない. その ため, 弾性予測応力による降伏関数 $f_{\text {trial }}=f\left(\sigma_{\text {trial }}, \lambda\right)$ が塑性論的許容条件

$$
f_{\text {trial }} \leq 0
$$

を満たす場合は弾性予測応力を真の解とし, 満たさな い場合は降伏したと判断し, 塑性整合条件

$$
f(\boldsymbol{\sigma}, \lambda)=0
$$




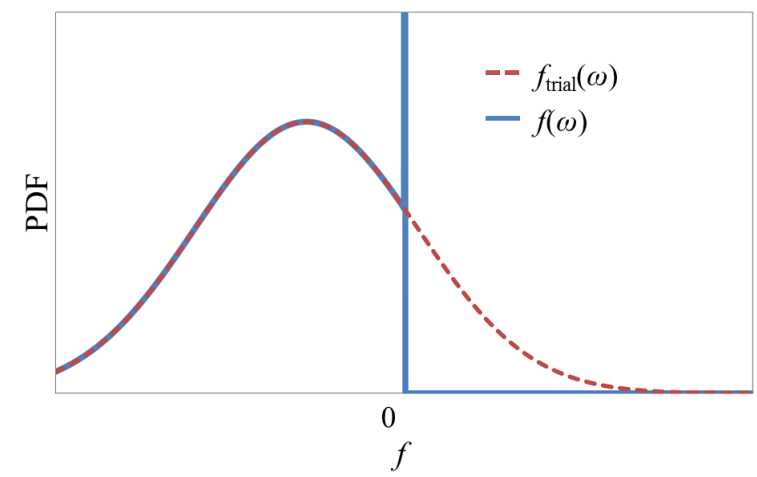

図-2 降伏関数の值の確率分布に関する変化 $\left(f_{\text {trial }}(\omega)\right.$ 及び $f(\omega))$

を満たすように，陰的に塑性乗数 $\Delta \lambda$ を求め，流れ則 に基づき応力を更新する.

$$
\boldsymbol{\sigma}=\boldsymbol{\sigma}_{\text {trial }}-\Delta \lambda \boldsymbol{D}: \partial_{\boldsymbol{\sigma}} f(\boldsymbol{\sigma}, \lambda)
$$

ここで, $\partial \boldsymbol{\sigma}$ は $\boldsymbol{\sigma}$ による偏微分を表しており, 関連流れ 則を適用した。

次に，物性場が確率分布を持つ場合を考えると，応答 場である歪や応力が確率分布を持つため, 降伏関数の值 も確率分布を持つ. 例えば, 弾性予測応力による降伏関 数の值 $f_{\text {trial }}(\omega)$ が正規分布をなす場合, $f_{\text {trial }}(\omega)$ は図一 2 の赤点線のような分布となる.ここで, $\omega$ は標本点を表 す.この時, $f_{\text {trial }}(\omega)$ の確率分布の一部は $f_{\text {trial }}(\omega) \leq 0$ で弾性域となるが, 残りは $f_{\text {trial }}(\omega)>0$ で塑性域とな る.そのため, リターンマッピング後の降伏関数の值 $f(\omega)$ は, $f_{\text {trial }}(\omega) \leq 0$ の領域はその確率分布を保持す るが, $f_{\text {trial }}(\omega)>0$ の領域では $f(\omega)=0$ となるよう に応力が更新される.その結果, リターンマッピング 後の降伏関数の值の確率分布は, 図-2 の青線のように, $f(\omega)=0$ でデルタ関数形状を持つ分布

$$
\operatorname{PDF}[f(\omega)]= \begin{cases}\left.\operatorname{PDF}\left[f_{\text {trial }}(\omega)\right]\right|_{f_{\text {trial }}=f} & (f(\omega)<0) \\ \bar{C}\left[0, f_{\text {trial }}\right] & (f(\omega)=0) \\ 0 & (f(\omega)>0)\end{cases}
$$

となる. $\operatorname{PDF}\left[f_{\text {trial }}(\omega)\right]$ は $f_{\text {trial }}(\omega)$ の確率密度関数, $\bar{C}\left[x, f_{\text {trial }}\right]$ は相補累積分布関数である.

(2) スペクトル確率リターンマッピングアルゴリズム

ここでは, 物性場が確率分布を持つ時, 応答場に 1 次 のスペクトル展開を適用することで確率的な降伏を評 価する SSRMA の概要を示す.

\section{a) スペクトル展開の整理}

物性場が確率分布を持つ場合, 全ての応答場が確率分 布を持つ. MCS では多数のサンプリングによりその確 率分布を評価するが, スペクトル展開では確率分布を確
率空間上のスペクトル成分（固有分布）の級数和として 表現する. SSFEM では, Karhunen-Loeve 展開16),17) (以下，KL 展開）と Polynomial Chaos 展開18),19)（以 下， PC 展開）の二つのスペクトル展開を用いる.ここ で，KL 展開は地盤物性の空間的相関を表現するための 展開であり，PC 展開は応答場の複雑な確率分布を表現 するための展開である. 詳細は付録 I 及び付録 II に記 載することとし, 以下では最低次を例にとりスペクト ル展開を説明する。

ヤング率 $E$ と降伏応力 $\sigma_{\mathrm{Y}}$ が正規分布をなす独立な 確率変数である場合を考える.この時, 1 次の $\mathrm{KL}$ 展開 を適用すれば, $E(\omega)$ 及び $\sigma_{\mathrm{Y}}(\omega)$ は期待值と分散を用い て以下のようにスペクトル展開できる.

$$
\begin{aligned}
E(\omega) & =\langle E\rangle+\sqrt{\operatorname{VAR}(E)} \xi_{1}(\omega) \\
\sigma_{\mathrm{Y}}(\omega) & =\left\langle\sigma_{\mathrm{Y}}\right\rangle+\sqrt{\operatorname{VAR}\left(\sigma_{\mathrm{Y}}\right)} \xi_{2}(\omega)
\end{aligned}
$$

ここで, $\langle X\rangle$ 及び $\operatorname{VAR}(X)$ は確率変数 $X(\omega)$ の期待值 及び分散を表す. また, $\xi_{1}(\omega)$ 及び $\xi_{2}(\omega)$ は期待值 0 で 分散 1 の独立な正規確率変数であり, 確率空間上の固 有関数である. 0 次のスペクトル展開 (第一項) は確率 変数の期待值であり決定論的な取り扱いとなるが，1次 以上のスペクトル展開（第二項）を考慮することで確 率変数として取り扱うことができる.

一方, 変位 $\boldsymbol{u}(\omega)$ 等の応答場は物性場をパラメータと した行列方程式の解として与えられるため, $E(\omega)$ 及び $\sigma_{Y}(\omega)$ 両方の不確実性の影響を受ける. 変位 $\boldsymbol{u}(\omega)$ 等に 対して 1 次の PC 展開を適用すると, 以下のようにス ペクトル展開される.

$$
\boldsymbol{u}(\omega)=\boldsymbol{u}^{(0)}+\boldsymbol{u}^{(1)} \xi_{1}(\omega)+\boldsymbol{u}^{(2)} \xi_{2}(\omega)
$$

ここで，応答場に 1 次の $\mathrm{PC}$ 展開を適用することは，以 下の関係を用いて応答場の期待值 $\langle u\rangle$ と分散 $\operatorname{VAR}(u)$ を評価することに対応する。

$$
\langle\boldsymbol{u}\rangle=\boldsymbol{u}^{(0)}, \quad \operatorname{VAR}(\boldsymbol{u})=\left(\boldsymbol{u}^{(1)}\right)^{2}+\left(\boldsymbol{u}^{(2)}\right)^{2}
$$

式（10）からわかるように，スペクトル展開した応答 場は各物性場の確率空間上の固有関数 $\xi_{i}(\omega)$ の重ね合 わせとして表現されるため, 各物性場の不確実性から の寄与がそれぞれ独立に考慮される. 式 (8)〜式（10） のように確率変数に対してスペクトル展開を適用する 場合, 確率変数の確率的特性は確率空間上の固有関数 $\xi_{i}(\omega)$ により決定される. また, $\xi_{i}(\omega)$ は以下の直交性 を持つ。

$$
\left\langle\xi_{i}(\omega) \xi_{j}(\omega)\right\rangle=\delta_{i j}
$$

b) スペクトル確率リターンマッピングアルゴリズム の整理

応答場に PC 展開を適用する場合, 応力 $\boldsymbol{\sigma}(\omega)$ や降伏 関数 $f(\omega)$ も $\mathrm{PC}$ 展開される. $\mathrm{PC}$ 展開次数を 0 次とし た場合は, 応力や降伏関数の期待值のみを考慮し, 降 
伏を決定論的に取り扱うことに対応する．降伏におい て種々の地盤物性の不確実性を考慮するためには，よ り高次の PC 展開を考慮する必要がある. SSRMA で は, 確率空間への最小限の拡張として, 降伏に関係す る応力, 塑性乗数及び降伏関数に 1 次の $\mathrm{PC}$ 展開を適 用する. すると, 応力 $\boldsymbol{\sigma}(\omega)$, 塑性乗数 $\lambda(\omega)$ 及び降伏 関数 $f(\omega)$ は以下のように与えられる.

$$
\begin{aligned}
\boldsymbol{\sigma}(\omega) & =\sum_{i=0}^{M} \boldsymbol{\sigma}^{(i)} \xi_{i}(\omega) \\
\lambda(\omega) & =\sum_{i=0}^{M} \lambda^{(i)} \xi_{i}(\omega) \\
f(\omega) & =\sum_{i=0}^{M} f^{(i)} \xi_{i}(\omega)
\end{aligned}
$$

ここで, $M$ は独立な正規確率変数の数であり, $E$ と $\sigma_{\mathrm{Y}}$ の KL 展開次数をそれぞれ 1 次とする場合には $M=2$ となる. また， $\xi_{0}=1$ をダミー変数として定義した。

確率変数をスペクトル展開する場合, リターンマッ ピングアルゴリズムにおける式 (3) 及び式 (6) は, スペ クトル展開係数に対する関係式に拡張される. 式 (12) の $\xi_{i}(\omega)$ の直交性より, 式 $(3)$ 及び式 $(6)$ に $\xi_{i}$ を乗じ期 待値を取れば, 弾性予測応力の PC 展開係数に対する 関係式は

$$
\boldsymbol{\sigma}_{\text {trial }}^{(i)}=\boldsymbol{\sigma}^{(i)}+\left\langle\xi_{i}(\omega) \boldsymbol{D}(\omega): \Delta \boldsymbol{\epsilon}(\omega)\right\rangle
$$

となり, 更新する応力の $\mathrm{PC}$ 展開係数の関係式は以下 で与えられる。

$$
\boldsymbol{\sigma}^{(i)}=\boldsymbol{\sigma}_{\text {trial }}^{(i)}-\left\langle\xi_{i}(\omega) \Delta \lambda(\omega) \boldsymbol{D}(\omega): \partial \boldsymbol{\sigma} f(\omega)\right\rangle
$$

ヤング率や降伏応力等の物性場が正規分布をなす場合 の確率的な降伏では, 例えば図-2 からわかる通り, 降 伏関数の值が 0 以上となる確率が常に存在するため, 弾 塑性体は常に一定の確率で降伏が生じる. 従って, 確 率変数にスペクトル展開を適用する場合, 降伏を判断 する塑性論的許容条件は常に成立しないため, 本条件 を設定する必要はない。

一方, 塑性整合条件は適切に設定する必要がある。リ ターンマッピング後の降伏関数の值の確率分布は, 図2 に示す通りに, $f_{\text {trial }}(\omega)>0$ の領域はすべて $f(\omega)=0$ にマッピングされるため, 図 -2 の青線のような分布と なる. 1 次の $\mathrm{PC}$ 展開を適用する事は期待值と分散のみ を評価することに対応するため, SSRMA では降伏関 数 $f(\omega)$ の期待值と分散を図-2 の青線のそれに等しく なるように応力を更新することになる，その結果，塑 性整合条件は式 (11) の PC 展開係数と期待值及び分散 の関係より, 以下のように拡張される.

$$
\begin{aligned}
& f^{(0)}-\langle f\rangle=0 \\
& \sum_{i=1}^{M}\left(f^{(i)}\right)^{2}-\operatorname{VAR}(f)=0
\end{aligned}
$$

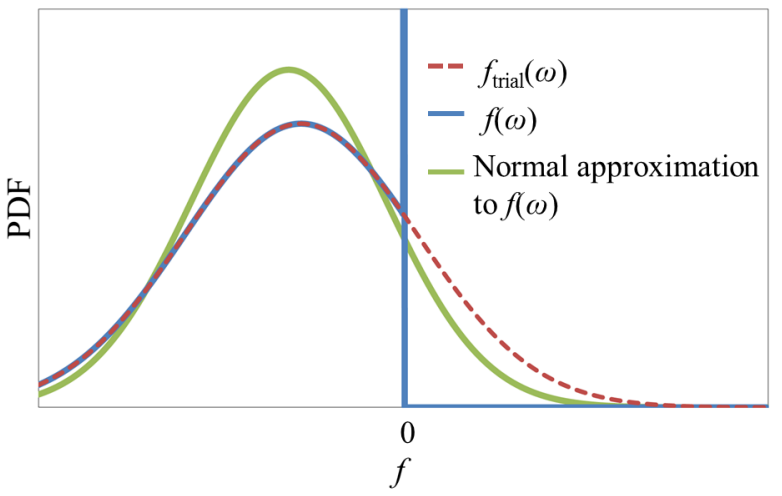

図-3 降伏関数の值の確率分布に関する変化 $\left(f_{\text {trial }}(\omega), f(\omega)\right.$ 及び正規分布で近似した $f(\omega))$

ここで, リターンマッピング後の降伏関数の期待值 $\langle f\rangle$ と分散 $\operatorname{VAR}(f)$ は, 式 (7) より以下で求められる.

$$
\begin{aligned}
\langle f\rangle & =\int_{-\infty}^{0} f_{\text {trial }} \mathrm{PDF}\left[f_{\text {trial }}\right] d f_{\text {trial }} \\
\operatorname{VAR}(f) & =\int_{-\infty}^{0} f_{\text {trial }}^{2} \mathrm{PDF}\left[f_{\text {trial }}\right] d f_{\text {trial }}-\langle f\rangle^{2}
\end{aligned}
$$

さらに, $\xi_{i}(\omega)$ が独立な正規確率変数であり, $f^{(i)}$ と $f_{\text {trial }}^{(i)}$ の関係は任意の值に対して定義されることを考慮すれ ば, 降伏関数 $f(\omega)$ の PC 展開係数は以下で与えられ $ろ^{12), 13)}$.

$$
f^{(i)}= \begin{cases}\langle f\rangle & (i=0) \\ \sqrt{\frac{\operatorname{VAR}(f)}{\operatorname{VAR}\left(f_{\text {trial }}\right)}} f_{\text {trial }}^{(i)} & (i \neq 0)\end{cases}
$$

この確率空間に拡張された塑性整合条件が決定論的なリ ターンマッピングアルゴリズムと SSRMA で大きく異 なる点である.これは確率分布の観点では図-3のよう に整理できる. 物性場が正規分布をなす場合, SSRMA で降伏関数の期待值と分散を評価することは, リター ンマッピング後の降伏関数 $f(\omega)$ （図-3 の青線）を期待 值と分散が等しい正規分布 (図-3 の緑線) で近似する ことに対応する.

図-4に SSRMA の評価フローを示す。ここで，塑性 論的許容条件を点線で示しているが, 確率的な降伏では 降伏関数の值が 0 以上となる確率が常に存在すること から, 評価の際に条件判定を行わない. 図-4 からわか る通り, SSRMA の評価フローは, 式 (16) 及び式 (17) のように PC 展開係数に対する計算が必要であるもの の, 図-1 の陰的弾性予測子/リターンマッピングアルゴ リズムの評価フローと基本的な流れは同じである. 唯 一異なるのは, 塑性論的整合条件において, $f=0$ では なく, 期待值 $\langle f\rangle$, 分散 $\operatorname{VAR}(f)$ の正規分布となるよう に応力を更新する点である. SSRMA はリターンマッピ ングアルゴリズムを確率空間へ最小限拡張したもので あり, SSRMA の PC 展開係数を 0 次とすれば SSRMA は完全に決定論的なリターンマッピングアルゴリズム 


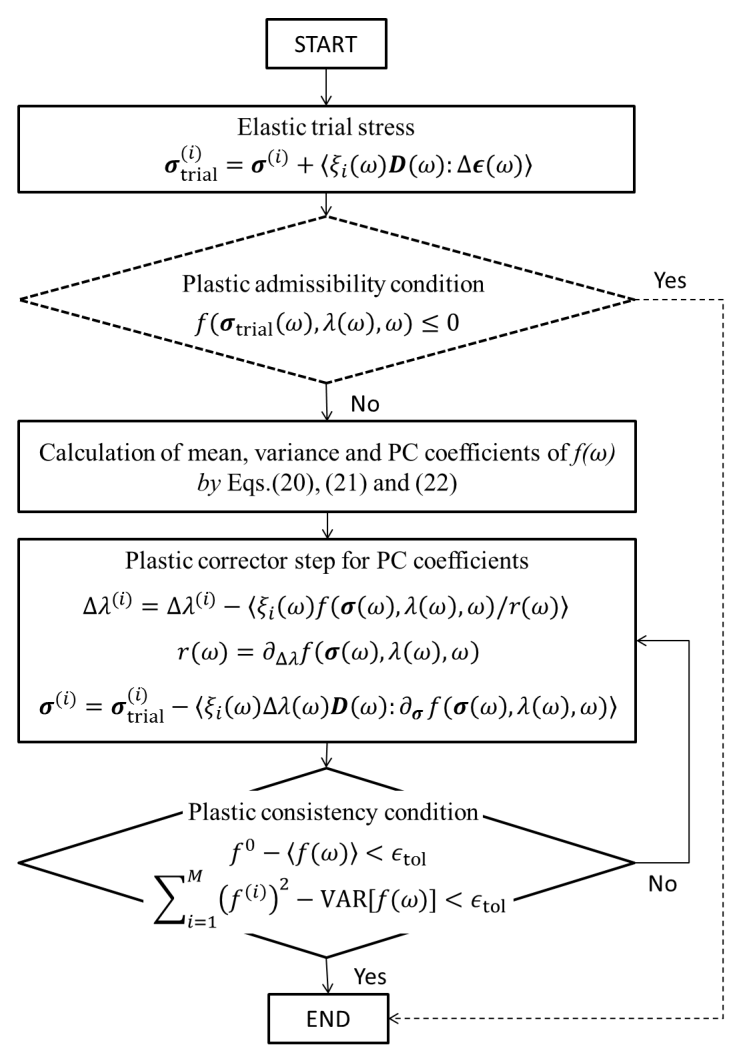

図-4 SSRMA の評価フロー

に一致する.

SSRMA の妥当性を確認するため, せん断歪 $\gamma$ を決 定論的に増加させたときの応力-歪関係を評価し, MCS の結果と比較する．載荷除荷サイクルを含む SSRMA の詳細な検証については, 筆者らによって示されてい る $^{13)}$.ここでは簡単のため, 材料の降伏基準は 1 次元 弾完全塑性 von Mises 降伏基準を用いる. 降伏関数はせ ん断応力 $\tau$ と降伏応力 $\sigma_{\mathrm{Y}}$ を用いて以下で与えられる.

$$
f=\sqrt{3}|\tau|-\sigma_{\mathrm{Y}}
$$

この時, 決定論的な結果はバイリニア型の応力歪関係 となる. 解析物性值として, せん断弾性係数と降伏応 力を正規分布をなす確率変数とし, せん断弾性係数の 期待值及び変動係数を $70 \mathrm{MPa}$ 及び $30 \%$, 降伏応力の 期待值及び変動係数を $0.4 \mathrm{MPa}$ 及び $20 \%$ とする. また, 比較対象とする MCS の計算は, せん断弾性係数と降伏 応力の入力值を確率分布に従って 5000 回発生させて計 算する. 図-5 に SSRMA 及びMCS を用いて評価した 応力-歪関係の結果を示す. 図 -5 には期待値及び期待値 \pm 標準偏差に加え, 参考のため, せん断弾性係数及び降 伏応力の期待值を用いて評価した決定論的な結果を示 している.これらの結果から, SSRMA と MCS の期待 值及び期待值 \pm 標準偏差の結果はよく一致しているこ とがわかる。このように, SSRMA は降伏に関係する 応答場の期待值と分散のみを評価するモデルであるが,

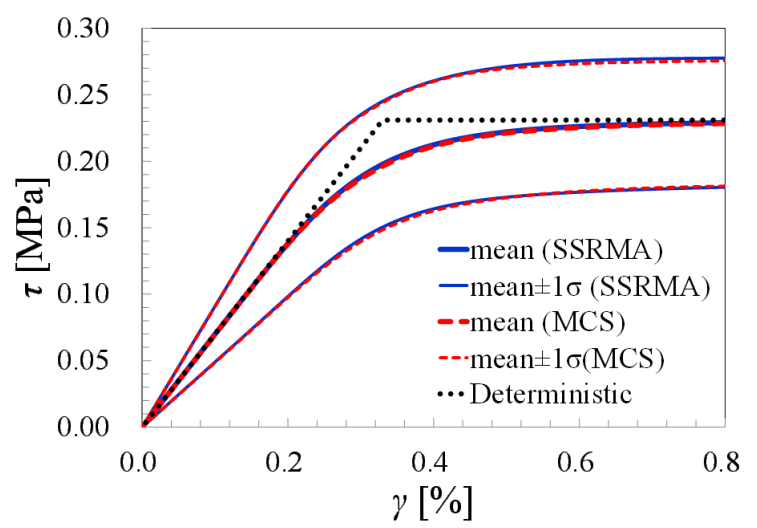

図-5 SSRMA による応力-歪関係の評価結果 $\left(G_{0}=70 \mathrm{MPa}\right.$ (変動係数 $30 \%), \sigma_{\mathrm{Y}}=0.4 \mathrm{MPa}($ 変動係数 $20 \%)$ )

MCS と比べ期待值と分散を効率よく評価することが可 能であることがわかる.

図-5に示した SSRMA と MCS の期待值の応答は, 決定論的な結果と比べて, 小さい歪レベルからなめら かな非線形性が現れていることがわかる，もし，せん 断弾性係数と降伏応力のばらつきを地盤物性の空間的 なばらつきではなく, 地盤を構成する土粒子の物性の ばらつきとして考えれば，図-5 の結果は土粒子の物性 のばらつきによる確率的な降伏を評価したことに対応 する. このとき, 図-5 の期待值は土粒子の平均挙動を 表しており, 実験で得られる地盤の非線形特性に対応 すると解釈できる.

\section{3. 履歴特性の評価}

ここでは，地盤は様々な土粒子から構成され，地盤 の挙動はそれらの土粒子の平均挙動として現れるとい う考え方に基づき, SSRMA を用いて非排水粘土の履 歴特性を評価する. まず, 既存の非排水粘土の試験結 果よりせん断弾性係数 $G_{0}$ 及び非排水せん断強度 $S_{u}$ を 整理し, SSRMA により非排水粘土の履歴曲線及び動 的変形特性を評価する。

\section{(1) 数值実験の方法}

履歴特性を評価するため, SSRMA を用いて動的変 形試験を想定した数值実験を実施する. 本数值実験で は, 地盤を構成する土粒子の物性として, せん断弾性 係数とせん断強度のばらつきを考慮し, SSRMA によ り確率的な降伏を評価する。このとき, 応答場の期待 值は土粒子の平均挙動を表しており, 地盤の挙動に対 応すると考えられる. 具体的な計算手順としては, せ ん断歪 $\gamma$ を最大值 $\gamma= \pm \gamma_{\max }$ の間で決定論的に変化 させて繰り返し載荷し, 応力-歪関係の履歴曲線を計算 する.その後, 動的変形試験と同様に, $\gamma_{\max }$ を段階的 に増加させ，それぞれの履歴曲線の結果から動的変形 


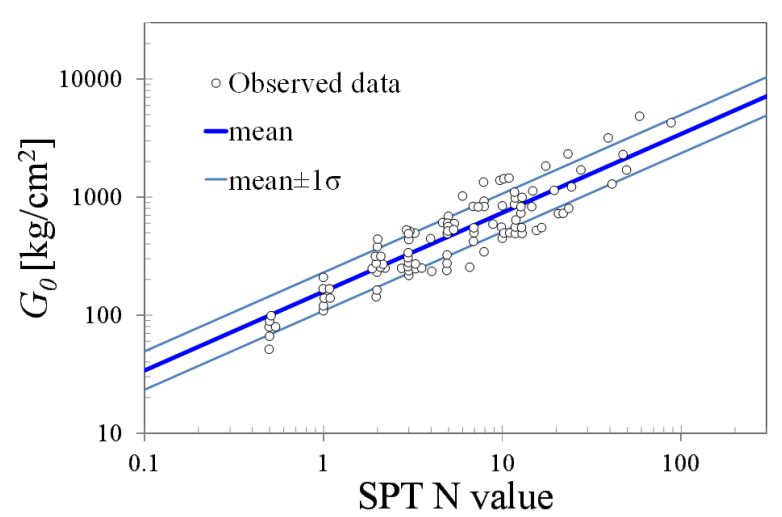

図-6 せん断弾性係数 $G_{0}$ の $\mathrm{N}$ 值の関係 $\left(\right.$ 測定值 ${ }^{20)}$, 期待 值 ${ }^{20)}$, 期待值 \pm 標準偏差)

特性（せん断剛性比 $G / G_{0}$ 及び減衰 $h$ の歪依存性）を 評価する.ここで, Sett らと同様14)に, 試験体の形状 は考慮せず，局所的な数值解析により土粒子の物性の ばらつきの影響のみを評価する。また，評価手法の有 効性と土粒子の物性のばらつきが履歴特性に与える影 響を評価することを目的とするため, 土粒子の降伏モ デルは弾完全塑性 von Mises モデルを用いる.このと き, 弾完全塑性 von Mises モデルの降伏関数は式 (23) で与えられる. 降伏応力 $\sigma_{\mathrm{Y}}$ は非排水せん断強度 $S_{u}$ と $\sigma_{\mathrm{Y}}=\sqrt{3} S_{u}$ の関係にある. 数值解析に必要な物性值は せん断弾性係数 $G_{0}$ と非排水せん断強度 $S_{u}$ の 2 変数で あり, 必要な入力情報はそれらの期待值及び分散また は変動係数となる.

\section{（2）地盤物性の不確実性の評価}

ここでは, SSRMA の入力条件であるせん断弾性係 数 $G_{0}$ 及び非排水せん断強度 $S_{u}$ の期待值と変動係数を 整理する．地盤を構成する土粒子の物性のばらつきを 直接評価することは困難であるため, Sett らの評価方 法14)に倣い, 複数の試験体から得られる物性のばらつ きが地盤を構成する土粒子の物性のばらつきに等しい として評価する。本論文では Hara ら 20)によって整理 された, 沖積粘土の標準貫入試験の $N$ 值とせん断弾性 係数 $G_{0}$ 及び非排水せん断強度 $S_{u}$ の関係を用いる.

$$
\begin{aligned}
G_{0} & =158 N^{0.668}\left(\mathrm{~kg} / \mathrm{cm}^{2}\right) \\
S_{u} & =0.297 N^{0.720}\left(\mathrm{~kg} / \mathrm{cm}^{2}\right)
\end{aligned}
$$

測定值は不確実性を伴うことが通常であるが，決定 論的解析では工学的判断により, 式 (24) 及び式 (25) の 関係式をそのまま用いる. 一方, 確率論的解析では, 式 (24) 及び式 (25) の関係式は期待值として用いられ, それ らのばらつきも考慮する必要がある. 図-6 及び図-7に Hara ら 20)によって整理された $N$ 值とせん断弾性係数 $G_{0}$ 及び非排水せん断強度 $S_{u}$ の関係の測定值と関係式 を示す.ここで, 図-6 及び図-7には, 測定值から評価

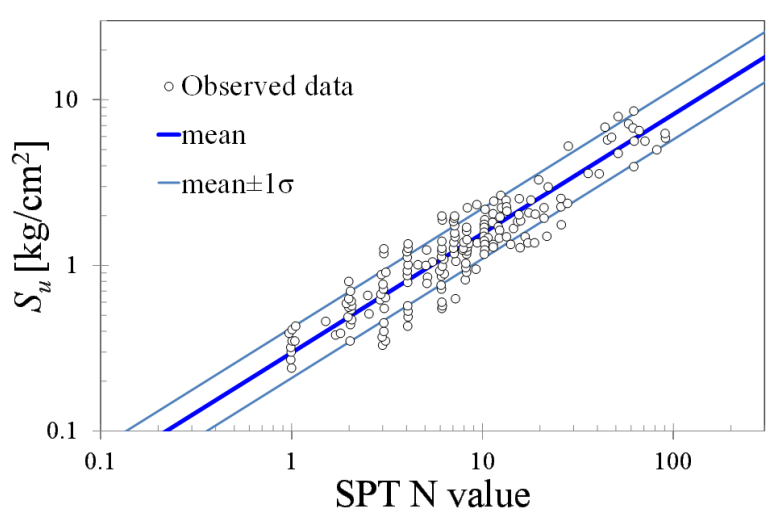

図-7 非排水せん断強度 $S_{u}$ と $\mathrm{N}$ 值の関係 (測定值 ${ }^{20)}$, 期待 值 ${ }^{20)}$, 期待值 \pm 標準偏差)

した期待值 \pm 標準偏差の結果も記載している.このと き, 関係式に対する分散 $\operatorname{VAR}_{\epsilon}\left(G_{0}\right)$ 及び $\operatorname{VAR}_{\epsilon}\left(S_{u}\right)$ は 以下のように評価される.

$$
\begin{aligned}
& \operatorname{VAR}_{\epsilon}\left(G_{0}\right)=0.162^{2} \\
& \operatorname{VAR}_{\epsilon}\left(S_{u}\right)=0.152^{2}
\end{aligned}
$$

さらに, 物性場の不確実性には, 上記で評価した関 係式の不確かさ $\delta_{\epsilon}$ の他に, 実験時の誤差, つまり機材, 手順, 観測者による不確実性 $\delta_{e}$ も大きく影響すること が知られている21) 23). Phoon and Kulhawy はこれ らの不確実性を考慮するため, 確率論的な形式の関係式

$$
\begin{gathered}
G_{0}=158\left(N+\delta_{e}\left(G_{0}\right)\right)^{0.668} 10^{\delta_{\epsilon}\left(G_{0}\right)} \\
S_{u}=0.297\left(N+\delta_{e}\left(S_{u}\right)\right)^{0.720} 10^{\delta_{\epsilon}\left(S_{u}\right)}
\end{gathered}
$$

を提案し, 各物性場の変動係数を以下のように評価し ている21).

$$
\operatorname{COV}^{2}\left(G_{0}\right)=0.668^{2} \operatorname{COV}_{e}^{2}\left(G_{0}\right)+(\log 10)^{2} \operatorname{VAR}_{\epsilon}\left(G_{0}\right)
$$

$$
\operatorname{COV}^{2}\left(S_{u}\right)=0.720^{2} \operatorname{COV}_{e}^{2}\left(S_{u}\right)+(\log 10)^{2} \operatorname{VAR}_{\epsilon}\left(S_{u}\right)
$$

ここで, $\operatorname{VAR}_{\epsilon}\left(G_{0}\right)$ 及び $\operatorname{VAR}_{\epsilon}\left(S_{u}\right)$ は式 $(26)$ 及び式 (27) で評価した関係式に対する分散であり, $\mathrm{COV}_{e}$ は観 測誤差の変動係数である. Phoon and Kulhawyによれ ば, 観測誤差の変動係数 $\mathrm{COV}_{e}$ は標準貫入試験の場合 $15 \%$ ～ $55 \%$ であると整理されている22),23). また, Sett らは, せん断強度試験は多くの不確定要素を含むこと から, 確率弾塑性モデルを用いた履歴特性の評価におい て， $G_{0}$ 及び $S_{u}$ のばらつきをそれぞれ $15 \%$ 及び $45 \% に$ 設定している14). 本論文でも Sett ら ${ }^{14)}$ に倣い， $G_{0}$ 及 び $S_{u}$ のばらつきとして，それぞれ $15 \%$ 及び $45 \%$ を用 いる. すると, $G_{0}$ 及び $S_{u}$ の変動係数は以下のように 評価できる。

$$
\begin{aligned}
& \operatorname{COV}\left(G_{0}\right)=0.386 \\
& \operatorname{COV}\left(S_{u}\right)=0.484
\end{aligned}
$$


表-1 解析物性值

\begin{tabular}{|c|c|c|}
\hline Parameter & Mean [MPa] & COV [\%] \\
\hline Elastic shear modulus $G_{0}$ & 133 & $38.6 \%$ \\
\hline Yield stress $\sigma_{\mathrm{Y}}$ & 0.512 & $48.4 \%$ \\
\hline
\end{tabular}

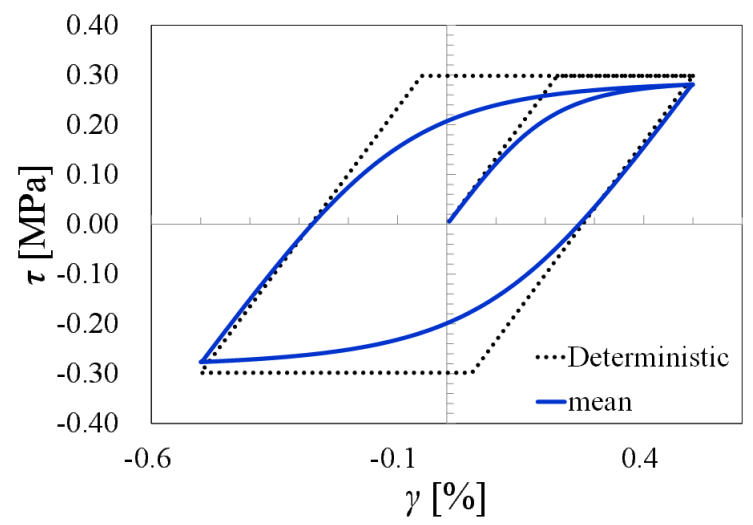

a) 期待値及び決定論の結果

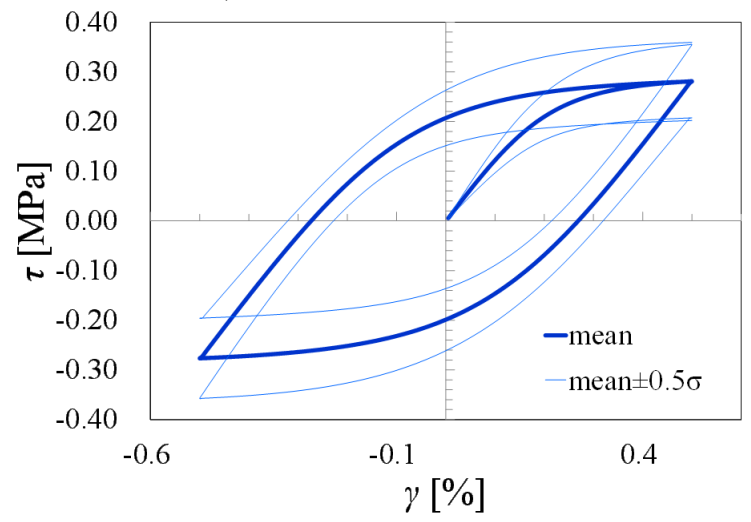

b) 期待値及び期待值 \pm 0.5 標準偏差

図-8 載荷除荷サイクルにおける応力-歪関係の比較 $(\gamma=$ $\pm 0.5 \%$ )

\section{（3）履歴曲線の評価}

ここでは，繰り返し載荷により評価した履歴曲線を 整理する. 解析物性值は標準貫入試験の $\mathrm{N}$ 值 $N=25$ の場合の物性值とし，その值は表-1の通りである.

図-8にせん断歪を $\gamma= \pm 0.5 \%$ で繰り返し載荷した 場合の履歴曲線の結果を示す。ここで，図-8 a)には SSRMA の期待值と決定論的な結果を示している. 決定 論的な結果はせん断弾性係数 $G_{0}$ とせん断強度 $S_{u}$ の期 待值を用いて評価した結果である。 また, 図-8b)に は SSRMA の期待值と期待值 \pm 0.5 標準偏差の結果を 示している. 図-8 a) からわかる通り, 決定論的な結 果はバイリニア型の履歴曲線を示す.一方, SSRMAの 期待值応答は, せん断弾性係数及び非排水せん断強度 の二つのパラメータのばらつきを考慮した弾完全塑性 モデルであるにもかかわらず，小さい歪レベルから非 線形特性が現れている. さらに, 図-8 b)に示す通り,

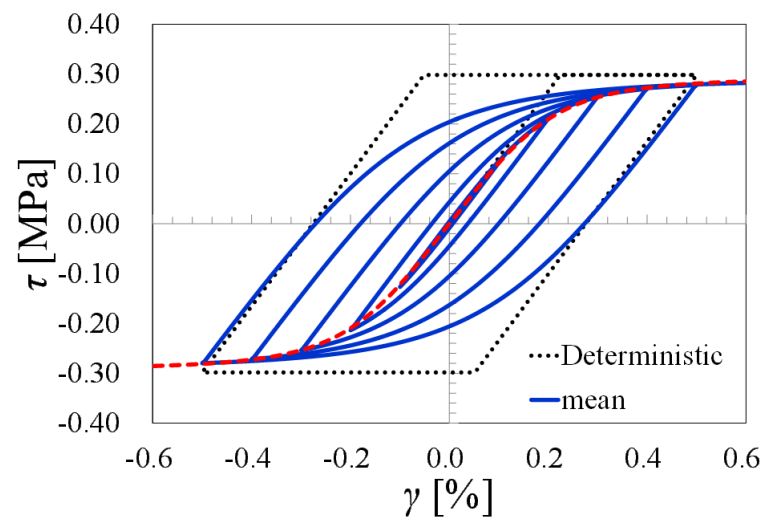

図-9 履歴曲線の評価結果 $(\gamma= \pm 0.5 \%)$

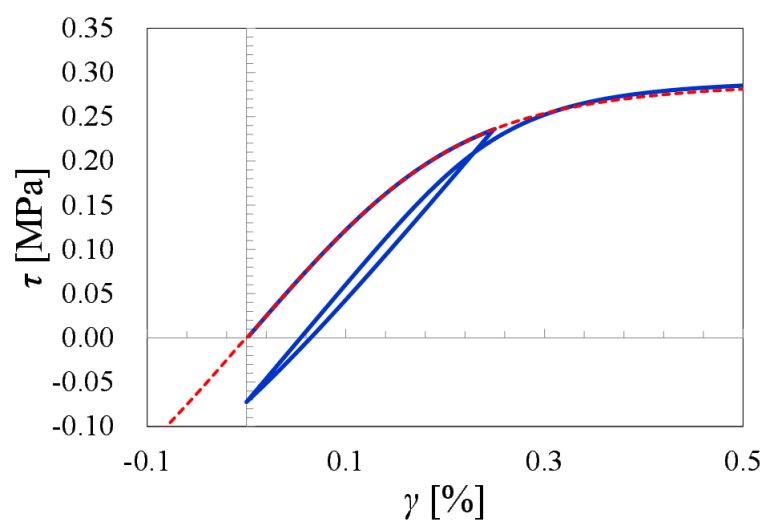

図-10 履歴曲線の評価結果 (非対称載荷除荷サイクル)

SSRMA を用いることで期待值だけでなくそのばらつ きも評価できる.これらの非線形特性は, 地盤を構成 する土粒子のせん断強度とせん断弾性係数のばらつき の影響である．地盤を構成する土粒子の物性のばらつ きを考慮すると, 常に応力状態の一部が降伏し, 残り は弾性状態となるため, 小さい歪レベルから大きい歪 レベルまでなめらかな非線形特性が現れる. 図-8のよ うななめらかな非線形特性は, FPK 方程式を用いた場 合 ${ }^{14)}$ と同様の結果である.

次に, 図-9 にせん断歪 $\gamma$ を $\pm 0.5 \%$ まで段階的に変 化させた場合の履歴曲線を示す.さらに，図-10にせん 断歪を非対称に変化させた場合の履歴曲線を示す。こ れらの結果からわかるように, 弾塑性モデルを確率空 間へ拡張することで, 土粒子の降伏モデルに単純な弾 完全塑性モデルを用いた場合であっても，骨格曲線（赤 点線）に沿ったなめらかな履歴曲線が得られることが わかる. また, 連続的な応力状態の変化に対して応力歪曲線の勾配が連続的に変化しており, 下負荷面モデ ル24),25) 等で実現される滑らか条件26) 29) を自動的に 満たしている. 本検討は 1 次元降伏関数を用いた検討 であるが, 塑性論に基づいた評価であるため, 3 次元問 題への適用も容易である. 


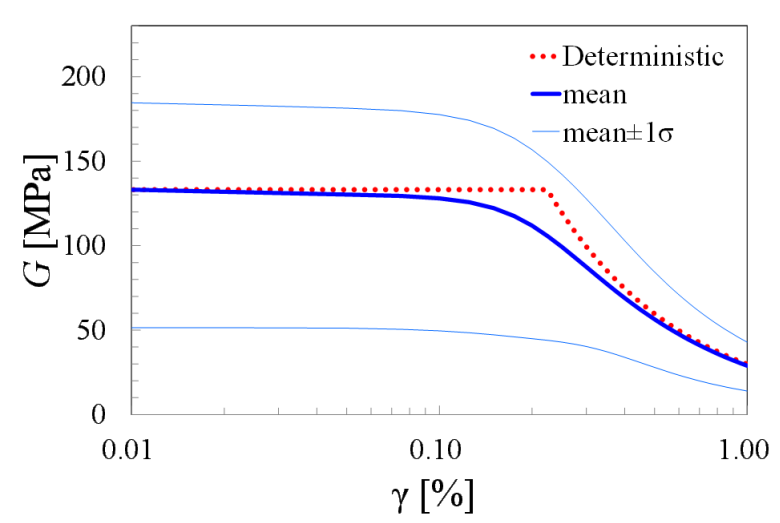

図-11 割線剛性 $G$ の $\gamma$ 依存性

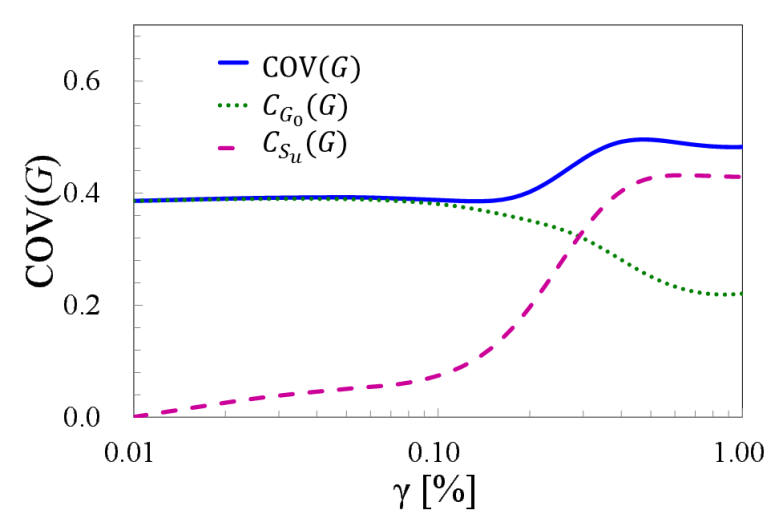

図-12 割線剛性 $G$ の変動係数と地盤物性のばらつきの影響

\section{(4) 動的変形特性の評価}

上記の応力-歪関係より, 動的変形特性 $\left(G / G_{0}-\gamma\right.$ 関 係及び $h-\gamma$ 関係）を評価する.

まず，図-11に割線剛性 $G$ の $\gamma$ 依存性の評価結果 を示す。ここで, 青線が期待值及び期待值 \pm 標準偏差 の結果である．また，参考のため赤点線でせん断弾性 係数 $G_{0}$ とせん断強度 $S_{u}$ の期待值から得られた決定 論的な結果を示している. 決定論的な履歴曲線はバイ リニア型であり，弾性状態と塑性状態が完全に区別さ れる．そのため, 決定論的な結果は降伏点となるせん 断歪 $\gamma_{\mathrm{Y}}=\left\langle\sigma_{\mathrm{Y}}\right\rangle / \sqrt{3}\left\langle G_{0}\right\rangle=0.22 \%$ までは $G_{0}$ に等し く, 降伏後はせん断歪に反比例して急激に減少してい く. 一方, 確率弾塑性モデルの期待值は小さい歪レベ ルから緩やかに減少する。 さらに, 図-12に $G$ の変動 係数 $\operatorname{COV}(G)$ とそれに対するせん断弾性係数 $G_{0}$ 及び 非排水せん断強度 $S_{u}$ のばらつきからの寄与 $C_{G_{0}}(G)$ 及 び $C_{S_{u}}(G)$ を示す. ここで, $G$ の変動係数 $\mathrm{COV}(G)$ は それぞれの物性場からの寄与 $C_{G_{0}}(G)$ 及び $C_{S_{u}}(G)$ の 二乗和平方根で与えられる.

$$
\operatorname{COV}(G)=\sqrt{C_{G_{0}}^{2}(G)+C_{S_{u}}^{2}(G)}
$$

図-12 から, 小さい歪レベルでは $G$ の変動係数 $\operatorname{COV}(G)$ は $39 \%$ 程度であり, 歪の増大とともに $50 \%$ 程度に変化

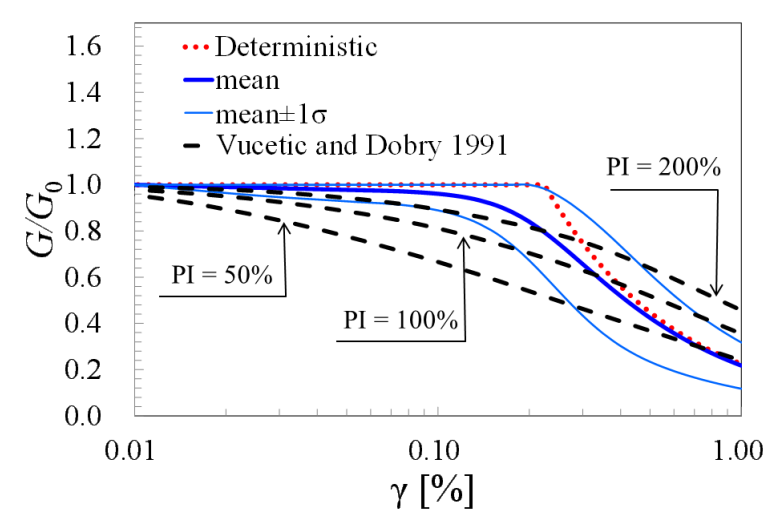

図-13 $G / G_{0}-\gamma$ 関係

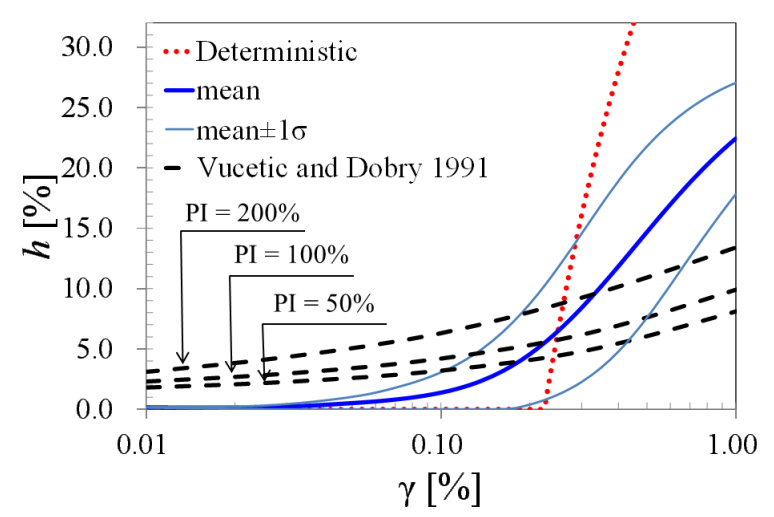

図-14 $h-\gamma$ 関係

していく.この変化は, 各物性場からの寄与の変化によ り理解できる. 小さい歪レベルでは全体の分布の多く が弾性域にあり, せん断弾性係数の寄与 $C_{G_{0}}(G)$ が支配 的であるため, $\operatorname{COV}(G)$ はせん断弾性係数 $G_{0}$ の変動 係数程度となっている. 歪が増加し降伏が進むにつれ, せん断強度の寄与 $C_{S_{u}}(G)$ が増大し, せん断弾性係数 の寄与 $C_{G_{0}}(G)$ が減少していき, 最終的にはせん断強 度の寄与 $C_{S_{u}}(G)$ が支配的となる。 その結果, $\operatorname{COV}(G)$ はせん断強度 $S_{u}$ の変動係数程度の值となる. このよう な地盤物性のばらつきの影響は, FPK 方程式を用いた 確率弾塑性モデルでは評価することができず, 応答場 にスペクトル展開を適用する SSRMA を用いることで 初めて可能となった。

次に, $G / G_{0}-\gamma$ 関係及び $h-\gamma$ 関係を評価する.こ こで, 繰り返し載荷時のせん断歪の最大值を $\gamma_{\max }$ とす るとき, $h$ は履歴吸収エネルギー $\int \tau(\gamma) d \gamma$ と割線剛性 による弾性歪エネルギー $\tau\left(\gamma_{\max }\right) \gamma_{\max } / 2$ の比を $4 \pi$ で除 して計算される. 図-13 及び図-14に $G / G_{0}-\gamma$ 関係及 び $h-\gamma$ 関係の評価結果を示す.ここで, 青線は期待值 及び期待值 \pm 標準偏差の結果である. また, 参考のた め, 決定論的な結果 (赤点線) と Vucetic and Dobryに より整理された高塑性粘土の実験值 ${ }^{30)}$ (黒破線) を示 している. 決定論的な履歴曲線はバイリニア型であり, 


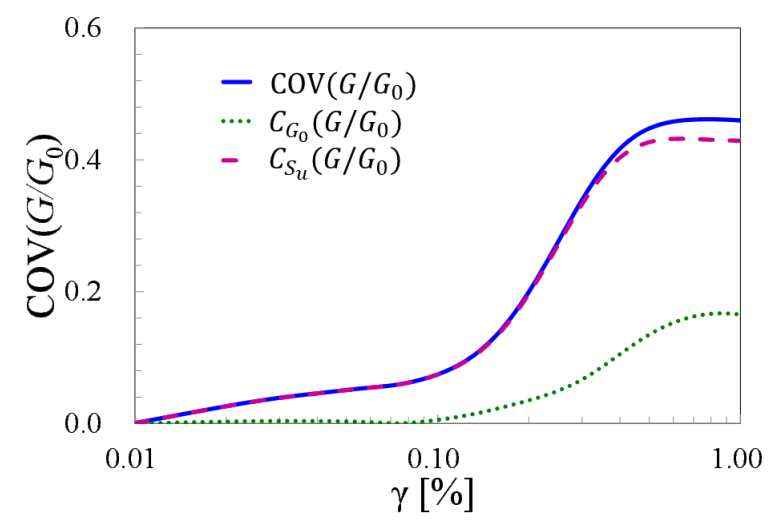

図-15 $G / G_{0}$ の変動係数と地盤物性のばらつきの影響

弾性状態と塑性状態が完全に区別される，そのため，決 定論的な結果は降伏点となるせん断歪 $\gamma_{\mathrm{Y}}=0.22 \%$ ま では $G / G_{0}$ 及び $h$ は変化せず, 降伏後, $G / G_{0}$ はせん 断歪 $\gamma$ に反比例して急激に減少し, $h$ は $2\left(1-\gamma_{\mathrm{Y}} / \gamma\right) / \pi$ で急激に増加する。一方, 確率弾塑性モデルの期待值 は小さい歪レベルから緩やかな変化が見られ，より現 実に近い結果を示していることがわかる．このように， 弾塑性モデルを確率空間に拡張することで, 単純な弾完 全塑性モデルを用いた場合でも，現実に近い $G / G_{0}-\gamma$ 関係及び $h-\gamma$ 関係が得られることがわかる.ただし, より定量的に実験值に近い動的変形特性を求めるには, 土粒子に対してより適切な降伏モデルを設定すること や物性値により適切な分布を用いること等を検討する 必要があると考えられる.

最後に, $G / G_{0}-\gamma$ 関係及び $h-\gamma$ 関係の不確実性を 評価する. 確率弾塑性モデルにおいて動的変形特性は 直接計算されるものではなく, 応答場である応力-歪関 係を求め, その応答場の関数として導出される. せん 断弾性係数とせん断強度に相関がない場合でも, 各応 答場の不確実性は独立ではない。そのため, 応答場間 の不確実性の相関を評価できなければ動的変形特性の 不確実性を正しく評価することはできない，FPK 方程 式を用いた確率弾塑性モデルでは物性場のばらつきの 影響を分離できないため, 動的変形特性の不確実性を 評価できない。一方, SSRMA ではスペクトル展開を用 いることで各物性場の不確実性からの寄与を計算でき るため, 動的変形特性の不確実性の評価が可能となる.

図-15に $G / G_{0}-\gamma$ 関係の変動係数 $\operatorname{COV}\left(G / G_{0}\right)$ と それに対するせん断弾性係数 $G_{0}$ 及び非排水せん断強度 $S_{u}$ からの寄与 $C_{G_{0}}\left(G / G_{0}\right)$ 及び $C_{S_{u}}\left(G / G_{0}\right)$ を示す.こ こで, $\operatorname{COV}\left(G / G_{0}\right), C_{G_{0}}\left(G / G_{0}\right)$ 及び $C_{S_{u}}\left(G / G_{0}\right)$ は, $\xi_{i}(\omega)$ の直交性を用いることで, 以下の関係式により評

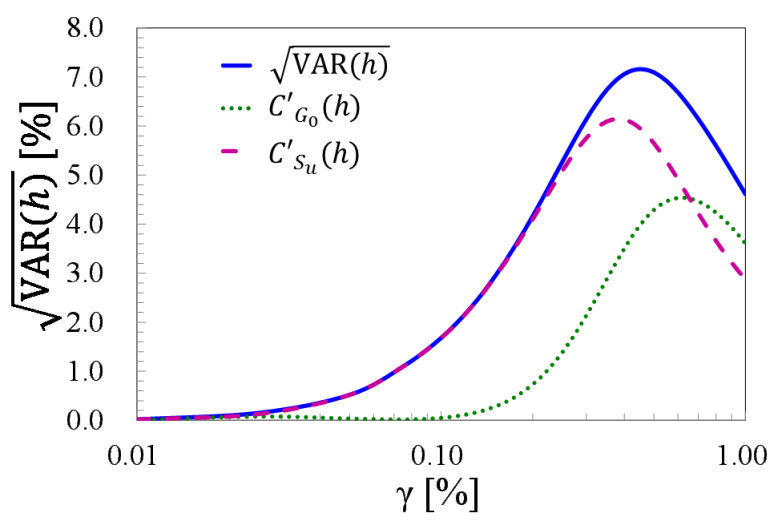

図-16 hの標準偏差と地盤物性のばらつきの影響

価できる.

$$
\begin{aligned}
\operatorname{COV}\left(G / G_{0}\right) & =\sqrt{C_{G_{0}}^{2}\left(G / G_{0}\right)+C_{S_{u}}^{2}\left(G / G_{0}\right)} \\
C_{G_{0}}\left(G / G_{0}\right) & =\frac{C_{G_{0}}(G)}{\langle G\rangle}-\frac{\sqrt{\operatorname{VAR}\left(G_{0}\right)}}{\left\langle G_{0}\right\rangle} \\
C_{S_{u}}\left(G / G_{0}\right) & =\frac{C_{S_{u}}(G)}{\langle G\rangle}
\end{aligned}
$$

ここで, 式 (36) 及び式 (37) の第一項は割線剛性 $G$ の 不確実性, 式 (36) の第二項はせん断弾性係数 $G_{0}$ の不 確実性に対応する。 また, 図-16に $h-\gamma$ 関係の標準偏 差 $\sqrt{\operatorname{VAR}(h)}$ とそれに対するせん断弾性係数 $G_{0}$ 及び 非排水せん断強度 $S_{u}$ からの寄与 $C_{G_{0}}^{\prime}(h)$ 及び $C_{S_{u}}^{\prime}(h)$ を示す. 変動係数は標準偏差を期待值で除したもので あるため, 期待值 $\langle h\rangle$ が 0 になると変動係数は発散す る.そのため, ここでは変動係数ではなく標準偏差を 示している. $\sqrt{\operatorname{VAR}(h)}, C_{G_{0}}^{\prime}(h)$ 及び $C_{S_{u}}^{\prime}(h)$ は以下の 関係式により評価できる.

$$
\begin{aligned}
\sqrt{\operatorname{VAR}(h)} & =\sqrt{C_{G_{0}}^{2}(h)+C_{S_{u}}^{2}(h)} \\
C_{G_{0}}^{\prime}(h) & =\langle h\rangle\left(\frac{\int\langle\tau\rangle C_{G_{0}}(\tau) d \gamma}{\int\langle\tau\rangle d \gamma}-\left.C_{G_{0}}(\tau)\right|_{\gamma=\gamma_{\max }}\right) \\
C_{G_{0}}^{\prime}(h) & =\langle h\rangle\left(\frac{\int\langle\tau\rangle C_{S_{u}}(\tau) d \gamma}{\int\langle\tau\rangle d \gamma}-\left.C_{S_{u}}(\tau)\right|_{\gamma=\gamma_{\max }}\right)
\end{aligned}
$$

ここで, $C_{G_{0}}(\tau(\gamma))$ 及び $C_{S_{u}}(\tau(\gamma))$ は応力の変動係数 に対する各物性場からの寄与である. また, 式 (39) 及 び式 (40) の第一項は履歴吸収エネルギー $\int \tau(\gamma) d \gamma$ の 不確実性, 第二項は割線剛性による弾性歪エネルギー $\tau\left(\gamma_{\max }\right) \gamma_{\max } / 2$ の不確実性に対応する.

図-15 及び図-16 からわかる通り, $G / G_{0}$ 及び $h$ の不 確実性は歪 $\gamma$ に依存して変化する. $\operatorname{COV}\left(G / G_{0}\right)$ はせ 几断強度からの寄与が支配的であり, 歪 $\gamma$ とともに増大 し, 一定の值へ漸近する. 一方, $h$ の標準偏差 $\sqrt{\operatorname{VAR}(h)}$ は小さい歪領域ではせん断強度からの影響が支配的で あり, 歪とともに増大するが，大きい歪領域で減少す る.この大きい歪領域における $\sqrt{\operatorname{VAR}(h)}$ の減少は, 
$h$ の定義から定性的に理解できる. $h$ は履歴吸収エネ ルギー $\int \tau(\gamma) d \gamma$ と割線剛性による弾性歪エネルギー $\tau\left(\gamma_{\max }\right) \gamma_{\max } / 2$ の比から求められる.これらはいずれ もせん断強度に関係する量であり, 降伏が進み応力状 態の大部分がせん断強度になると，分子と分母で不確 実性が相殺する. その結果, $\sqrt{\operatorname{VAR}(h)}$ は大きい歪領域 で減少すると考えられる。一方, 割線剛性 $G$ をせん断 弾性係数 $G_{0}$ で除した $G / G_{0}$ は， $G_{0}$ が弾性状態の変数 であるため，そのような不確実性の相殺は起こらない.

このような動的変形特性の不確実性は, 等価線形解 析や逐次非線形解析により確率論的評価を実施する場 合に重要な情報となる．等価線形解析ではせん断弾性 係数 $G_{0}$ に加え, $G / G_{0}$ 及び $h$ 等に不確実性を直接設定 する事になる ${ }^{31)}$.しかし, 図-15 及び図-16に示した 通り, $G / G_{0}$ 及び $h$ の不確実性は歪 $\gamma$ に対して一定の 值を取らないと考えられる. そのため, $G / G_{0}$ 及び $h$ の 不確実性の与え方によっては非保守的な評価になり得 るため，設定の方法に注意する必要がある.

\section{4. まとめ}

本論文では，スペクトル確率リターンマッピングア ルゴリズムによる確率弾塑性モデルを用いて非排水粘 土の履歴特性を評価した. その結果, 弾塑性モデルを 確率空間へ拡張することで, 単純な弾完全塑性モデル を用いた場合でも，より現実に近い履歴特性を評価す ることができた。これらの結果は, 原位置試験から得 られる地盤物性值を用いて, 履歴特性を数值解析的に 評価できる可能性を示唆しており, 地盤工学分野にお いて重要であると考えられる。また，スペクトル確率 リターンマッピングアルゴリズムでは地盤を構成する 土粒子の物性のばらつきが応答場に与える影響を独立 に評価できることから, 動的変形特性 $G / G_{0}-\gamma$ 関係 及び $h-\gamma$ 関係の不確実性を評価することができた。そ の結果, 動的変形特性の不確実性は歪と共に変化する ことがわかった.これらの結果は, 等価線形解析等に おいて動的変形特性の不確実性を直接設定する際に有 用な情報となると考えられる。

本検討では物性場のばらつきに対して正規分布を仮 定したが, 今後, より現実的な対数正規分布を対象と した検討も必要となると考えられる。 また, 地盤の試 験体の形状等も含めたより詳細な履歴特性の評価には, スペクトル確率リターンマッピングアルゴリズムをス ペクトル確率有限要素法に組み込み, 非線形スペクト ル確率有限要素法を構築することが必要となる。

\section{付録 I 物性場の KL 展開16),17)}

KL 展開は空間的相関を表現するためのスペクトル展 開であり, SSFEM では物性場に適用される。ヤング率 $E$ を空間的相関を持った確率変数とする場合, $E(\boldsymbol{x}, \omega)$ は期待值 $\langle E(\boldsymbol{x})\rangle$ と確率成分 $\alpha(\boldsymbol{x}, \omega)$ に分けることがで きる.

$$
E(\boldsymbol{x}, \omega)=\langle E(\boldsymbol{x})\rangle(1+\alpha(\boldsymbol{x}, \omega))
$$

ここで, $\boldsymbol{x}$ は空間座標， $\omega$ は標本空間の標本点である. $E(\boldsymbol{x}, \omega)$ にL 展開を用いると, 確率成分 $\alpha(\boldsymbol{x}, \omega)$ は以 下のように展開される。

$$
\alpha(\boldsymbol{x}, \omega)=\sum_{i=1}^{\infty} \sqrt{\lambda_{i}} \phi_{i}(\boldsymbol{x}) \bar{\xi}_{i}(\omega)
$$

ここで, $\lambda_{i}$ 及び $\phi_{i}$ は $E$ の共分散関数 $C\left(\boldsymbol{x}_{1}, \boldsymbol{x}_{2}\right)=$ $\left\langle\alpha\left(\boldsymbol{x}_{1}, \omega\right) \alpha\left(\boldsymbol{x}_{2}, \omega\right)\right\rangle$ の固有值及び固有関数である.

$$
\int C\left(\boldsymbol{x}_{1}, \boldsymbol{x}_{2}\right) \phi_{i}\left(\boldsymbol{x}_{2}\right) d \boldsymbol{x}_{2}=\lambda_{i} \phi_{i}\left(\boldsymbol{x}_{1}\right)
$$

また, $\bar{\xi}_{i}(\omega)$ は期待值 0 で分散 1 の正規確率変数であり, 以下の直交性を持つ.

$$
\left\langle\bar{\xi}_{i}(\omega) \bar{\xi}_{j}(\omega)\right\rangle=\delta_{i j}
$$

簡便のため, $\mathrm{KL}$ 展開次数を $\bar{M}$ とした場合の $E(\boldsymbol{x}, \omega)$ の KL 展開式を以下のように記載する.

$$
E(\boldsymbol{x}, \omega)=\sum_{i=0}^{\bar{M}} E^{(i)}(\boldsymbol{x}) \bar{\xi}_{i}(\omega)
$$

ここで, $\bar{\xi}_{0}=1$ はダミ一変数であり, $E^{(0)}(\boldsymbol{x})=\langle E\rangle$ 及 び $E^{(i)}(\boldsymbol{x})=\sqrt{\lambda_{i}} \phi_{i}(\boldsymbol{x})\langle E\rangle$ とした. すると, $E(\boldsymbol{x}, \omega)$ の分散 $\operatorname{VAR}(E)$ は同位置の共分散関数 $C\left(\boldsymbol{x}_{1}, \boldsymbol{x}_{2}\right)$ を用 いて,

$$
\operatorname{VAR}(E)=\langle E\rangle^{2} C(\boldsymbol{x}, \boldsymbol{x})
$$

で与えるため, 式 $(\mathrm{I} .4)$ の $\bar{\xi}_{i}(\omega)$ の直交性より, $\operatorname{VAR}(E)$ とスペクトル展開係数の間には以下の関係がある.

$$
\operatorname{VAR}(E)=\sum_{i=1}^{\infty}\left(E^{(i)}(\boldsymbol{x})\right)^{2}
$$

また, 降伏関数 $\sigma_{\mathrm{Y}}$ がヤング率 $E$ と独立な確率変数で ある場合， $\sigma_{\mathrm{Y}}$ は以下のように KL 展開できる.

$$
\sigma_{\mathrm{Y}}(\boldsymbol{x}, \tilde{\omega})=\sum_{i=0}^{\tilde{M}} \sigma_{\mathrm{Y}}^{(i)}(\boldsymbol{x}) \tilde{\xi}_{i}(\omega)
$$

ここで， $\tilde{M}$ は $\mathrm{KL}$ 展開次数であり, $\tilde{\xi}$ は $\bar{\xi}$ とは独立な 正規確率変数である.

\section{付録 II 応答場の PC 展開 ${ }^{18), 19)}$}

$\mathrm{PC}$ 展開は複雑な確率分布を表現するための展開であ り, SSFEM では変位 $\boldsymbol{u}$ 等の応答場に適用する。変位 
$\boldsymbol{u}(\boldsymbol{x}, \omega)$ を $\mathrm{PC}$ 展開すると, KL 展開の独立な確率変数 $\xi_{i}(\omega)$ を用いて以下のように展開される.

$$
\begin{gathered}
\boldsymbol{u}(\boldsymbol{x}, \omega)=\boldsymbol{a}_{0}(\boldsymbol{x}) \Gamma_{0}+\sum_{i_{1}=1}^{\infty} \boldsymbol{a}_{i_{1}}(\boldsymbol{x}) \Gamma_{1}\left(\xi_{i_{1}}(\omega)\right) \\
+\sum_{i_{1}=1}^{\infty} \sum_{i_{2}=1}^{i_{1}} \boldsymbol{a}_{i_{1} i_{2}}(\boldsymbol{x}) \Gamma_{2}\left(\xi_{i_{1}}(\omega), \xi_{i_{2}}(\omega)\right) \\
+\ldots
\end{gathered}
$$

ここで, $\Gamma_{p}$ は $p$ 次の Polynomial Chaos $(\mathrm{PC})$ であり,

$$
\begin{aligned}
\Gamma_{p}(\boldsymbol{\xi})= & (-1)^{p} \exp \left(\frac{1}{2} \boldsymbol{\xi}^{\mathrm{T}} \boldsymbol{\xi}\right) \\
& \times \frac{\partial^{p}}{\partial \xi_{m_{1}} \ldots \partial \xi_{m_{p}}} \exp \left(-\frac{1}{2} \boldsymbol{\xi}^{\mathrm{T}} \boldsymbol{\xi}\right)
\end{aligned}
$$

で与えられる.また， $\boldsymbol{\xi}(\omega)$ は任意の $\xi_{i}(\omega)$ を成分とす るべクトルである. 1 次の $\mathrm{PC}$ は $\Gamma_{1}\left(\xi_{i}(\omega)\right)=\xi_{i}(\omega)$ で あるが， 2 次以上の $\mathrm{PC}$ は $\xi$ 多項式で表されるため, $\mathrm{PC}$ 展開を用いることで複雑な確率変数を表現すること ができる.また, 簡便のため, 式 (II.1) を以下のように 表記する.

$$
\boldsymbol{u}(\boldsymbol{x}, \omega)=\sum_{n=0}^{P-1} \boldsymbol{u}^{(n)}(\boldsymbol{x}) \Psi_{n}(\{\xi(\omega)\})
$$

ここで, $P$ は独立な $\mathrm{KL}$ 展開の確率変数の数 $M, \mathrm{PC}$ 展開次数 $p$ により以下で求められる.

$$
P=1+\sum_{s=1}^{p} \frac{1}{s !} \prod_{k=0}^{s-1}(M+k)
$$

また, $\Psi_{n}(\{\xi(\omega)\})$ は, 以下の直交性を持つ.

$$
\left\langle\Psi_{n}(\{\xi(\omega)\}) \Psi_{m}(\{\xi(\omega)\})\right\rangle=\delta_{n m}
$$

例えば，ヤング率 $E(\boldsymbol{x}, \omega)$ 及び降伏応力 $\sigma_{\mathrm{Y}}$ が独立な確 率変数として式 (I.5) 及び式 (I.8) のように KL 展開す る場合, $\xi(\omega)$ は以下のように定義する.

$$
\xi_{i}(\omega)= \begin{cases}1 & (i=0) \\ \bar{\xi}_{i}(\omega) & (1 \leq i \leq \bar{M}) \\ \tilde{\xi}_{i}(\omega) & (\bar{M}+1 \leq i \leq \bar{M}+\tilde{M})\end{cases}
$$

ここで， $\bar{M}$ 及び $\tilde{M}$ はヤング率及び降伏応力の $\mathrm{KL}$ 展開 次数であり, $M=\bar{M}+\tilde{M}$ で与えられる.もし, KL 展 開次数及び $\mathrm{PC}$ 展開次数を 1 次 $(\bar{M}=\tilde{M}=1, p=1)$ とすれば，式 (10) が得られる.

\section{参考文献}

1) Ghanem, R. G. and Spanos, P. D.: Stochastic Finite Elements -A Spectral Approach-, Springer-Verlag, Berlin, 1991.

2) Anders, M. and Hori, M.: Stochastic finite element method for elasto-plastic body, Int. J. Numer. Methods Eng., Vol.46, No.11, pp.1897-1916, 1999.

3) Anders, M. and Hori, M.: Three-dimensional stochastic finite element method for elasto-plastic bodies, Int. J. Numer. Methods Eng., Vol.51, No.4, pp.449-478, 2001.
4) Hori, M. and Munasinghe, S.: Generalized HashinShtrikman variational principle for boundary-value problem of linear and non-linear heterogeneous body, Mechanics of Materials, Vol.31, No.7, pp.471-486, 1999.

5) Jeremic, B., Sett, K. and Kavvas, M. L.: Probabilistic elasto-plasticity: Formulation in 1D, Acta Geotech., Vol.2, No.3, pp.197-210, 2007.

6) Jeremic, B., Sett, K. and Kavvas, M. L.: Probabilistic elasto-plasticity: solution and verification in $1 \mathrm{D}$, Acta Geotech., Vol.2, No.3, pp.211-220, 2007.

7) Jeremic, B. and Sett, K.: On probabilistic yielding of materials, Commun. Numer. Methods Eng., Vol.25, No.3, pp.291-300, 2009.

8) Sett, K., Jeremic, B. and Kavvas, M. L.: The role of nonlinear hardening/softening in probabilistic elastoplasticity, Int. J. Numer. Anal. Meth. Geomech., Vol.31, No.7, pp.953-975, 2007.

9) Sett, K. and Jeremic, B.: Forward and backward probabilistic simulations in geotechnical engineering, Contemporary topics in in-situ testing, analysis, and reliability of foundations, Geotechnical Special Publications No. 186, ASCE, New York, pp.111, 2009.

10) Sett, K. and Jeremic, B.: Probabilistic yielding and cyclic behavior of geomaterials, Int. J. Numer. Anal. Meth. Geomech., Vol.34, No.15, pp.1541-1559, 2010.

11) Sett, K. and Jeremic, B.: Stochastic elastic-plastic finite elements, Comput. Methods Appl. Mech. Eng., Vol.200, No.9-12, pp.997-1007, 2011.

12) 羽場一基, 堀田渉, 畑明仁, 渡辺和明 : 非線形スペクト ル確率有限要素法に用いるリターンマッピングアルゴリ ズムの基礎的検討, 土木学会第 71 回年次学術講演会, pp.56, 2016.

13) 羽場一基, 堀田渉, 畑明仁, 渡辺和明, 堀宗朗 : スペク トル展開を用いた確率リターンマッピングアルゴリズム の基礎的検討, 土木学会論文集 (投稿中)

14) Sett, K., Unutmaz, B., Cetin, K., Koprivica, S. and Jeremic, B.: Soil uncertainty and its influence on simulated $G / G_{\max }$ and damping behavior, ASCE Journal of Geotechnical and Geoenvironmental Engineering, Vol.137, No.3, pp.218-226, 2011.

15) Simo, J. C. and Hughes, T. J. R.: Computational Inelasticity, Springer, New York, 1998.

16) Karhunen, K.: Uber lineare methoden in der wahrscheinlich-keitsrechnung, Annales Academiae Scientiarum Fennicae, Series A, I. MathematicaPhysica., Vol.37, pp.1-79, 1947.

17) Loeve, M.: Fonctions aleatoires du second ordre, Supplement to P. Levy, Processus Stochastic et Mouvement Brownien, 1948.

18) Wiener, N.: The homogeneous chaos, American Journal of Mathematics, Vol.60, pp.897-936, 1938.

19) Cameron, R. H. and Martin, W. T.: The orthogonal development of nonlinear functionals in series of Fourier-Hermite functionals, Annals of Mathematics, Vol.48, pp.385-392, 1947.

20) Hara, A., Ohta, T., Niwa, M., Tanaka, S. and Banno, T.: Shear modulus and shear strength of cohesive soils, Soils and Foundations, Vol.14, No.3, pp.1-12, 1974.

21) Phoon, K. K. and Kulhawy, F. H.: Evaluation of geotechnical property variability, Can. Geotech. J., Vol.36, No.4, pp.625-639, 1999.

22) Phoon, K. K., Kulhawy, F. H. and Grigoriu, M. D.: Reliability-based design of foundations for transmis- 
sion line structures, Electric Power Research Institute, Palo Alto, Report TR-105000, 1995.

23) Phoon, K. K. and Kulhawy, F. H.: Characterization of geotechnical variability, Can. Geotech. J., Vol.36, No.4, pp.612-624, 1999.

24) Hashiguchi, K.: Constitutive equations of elastoplastic materials with elastic-plastic transition, Journal of Applied Mechanics, Vol.47, No.2, pp.266-272, 1980.

25) Hashiguchi, K.: Subloading surface model in unconventional plasticity, International Journal of Solids and Structures, Vol.25, No.8, pp.917-945, 1989.

26) Hashiguchi, K.: Fundamental requirements and formulation of elastoplastic constitutive equations with tangential plasticity, International Journal of Plasticity, Vol.9, No.5, pp.525-549, 1993.

27) Hashiguchi, K.: Mechanical requirements and structures of cyclic plasticity models, International Journal of Plasticity, Vol.9, No.6, pp.721-748, 1993.
28) Hashiguchi, K.: The extended flow rule in plasticity, International Journal of Plasticity, Vol.13, No.1, pp.37-58, 1997.

29) 橋口公一: Fundamentals in Constitutive Equation, Continuity and Smoothness Conditions and Loading Criterion, 地盤工学会論文報告集, Vol.40, No.4, pp.155$161,2000$.

30) Vucetic, M. and Dobry, R.: Effect of soil plasticity on cyclic response, J. Geotech. Eng., Vol.117, No.1, pp.89-107, 1991.

31）畑明仁, 志波由紀夫: モンテカルロシミュレーションによ る地盤物性のばらつきが地震応答に与える影響に関する ケーススタディ, 土木学会論文集 A1 (構造・地震工学), Vol.65, No.1 (地震工学論文集第 30 巻), pp.202-213, 2009 .

(2016.11.4 受付, 2017.1.9 修正, 2017.2.18 受理)

\title{
APPLYING A STOCHASTIC ELASTO-PLASTICITY APPROACH TO EVALUATE INFLUENCE OF SOIL UNCERTAINTY ON HYSTERESIS CHARACTERISTICS
}

\author{
Kazumoto HABA, Wataru HOTTA, Hideaki SONOBE, Akihito HATA, \\ Kazuaki WATANABE and Muneo HORI
}

In this paper, the influence of soil uncertainty on hysteresis characteristics is evaluated by applying a stochastic elasto-plastic model to simulate the stress-strain relation of undrained clay. The stochastic model is based on stochastic return mapping algorithm which is expanded by spectral expansion. It is shown that the stochastic approach can evaluate more realistic hysteresis characteristics, even with elastic-perfectly plastic von Mises model. The uncertainty of dynamic deformation characteristics is estimated by calculating the influence of soil uncertainty on the response fields. 